\title{
Justification of promising areas of development of agricultural organizations
}

\author{
Fayaz Avkhadiev*, Nail Asadullin, Ilgizar Gainutdinov, and Liliya Mikhailova \\ Kazan State Agrarian University, Kazan 420015, Russia
}

\begin{abstract}
The relevance of the article topic is connected with the need to study the issues of increasing efficiency of agricultural enterprises at the regional level. The research goal is to develop proposals for improving the functioning of agricultural enterprises. The novelty of the research lies in the justification of proposals in order to improve the efficiency of agricultural organizations. The article presents results of the analysis of state indicators and development of the main agricultural branches in the Pre-Kama zone of the Republic of Tatarstan. The research results can be used to justify promising areas for the development of agricultural organizations.
\end{abstract}

\section{Introduction}

The main goal of any production is to generate income and meet the growing needs of the population in basic food products. Specifically for a commodity producer, the goal of economic activity is to obtain a large volume of high-quality products and reduce the cost of their production.

Product manufacturers, supplying products to the market, begin to compete for buyers, who lose this competition. Those who lose incur losses and leave this market. Under such conditions, each commodity producer thinks about such a level of enterprise performance that will allow the company to withstand competition and occupy a stable niche in the market. First of all, the main reason for the unstable situation of agricultural enterprises is the low economic efficiency of their functioning $[1,2]$.

Basic foodstuffs for the population are supplied by agriculture. Improving the functioning of enterprises and agriculture is currently the main problem of the domestic economy. It requires the development of various measures, starting with study of this concept, study of assessment methods and development of various scenarios for increasing efficiency of agricultural enterprises [3, 4].

\section{Materials and Methods}

The theoretical and methodological basis of the study were works of foreign and domestic agricultural economists on the topic under study: legislative acts, methodological foundations of modern theories on the effectiveness of methods for assessing it, state development programs and regulatory acts of the Russian Federation on the regulation of agri-food policy, materials from international and all-Russian scientific and practical conferences. During the research, we used data of the Federal State Statistics Service of the Russian Federation, the Ministry of Agriculture of the Russian Federation, the Ministry of Agriculture and Food of the Republic of Tatarstan, and planning or reporting documents of agricultural organizations.

When performing the research, the following methods were used: monographic, abstract-logical, economic-statistical, economic-mathematical and etc.

\section{Results and discussion}

The basic principle of management is to ensure a steady increase in production based on the rational use of all resources.

The essence of management is not simply profitmaking, but ensuring high growth rates with decreasing costs per unit of output. This can only be achieved by using a rational agricultural system.

Each individual element of the management mechanism represents a whole major problem.

All levers of the management mechanism should be aimed at solving the following problems: the most efficient and economical use of resources, increasing output per unit of expenditure of these resources and a steady increase in labor productivity. Almost all of this comes down to increasing the efficiency of production.

As an object of study, we selected enterprises of the Pre-Kama economic zone, since this zone reflects the general trends in the development of agricultural production in the Republic of Tatarstan. Natural and climatic conditions affect the specialization of economic zones. Agricultural enterprises of Pre-Kama economic zone have a livestock sector. [5]

Pre-Kama economic zone occupies $16.3 \%$ of the territory of the northern part of the Republic of Tatarstan. This zone includes the following municipal

Corresponding author: fn1973@mail.ru 
areas - Baltasinsky, Sabinsky, Kukmorsky, Tyulyachinsky, Mamadyshsky, Rybno-Slobodsky.

The article studies climatic conditions and the condition of agricultural industries in the areas included in the Pre-Kama economic zone of the Republic of Tatarstan.

The areas of Predkamsk economic zone are located in the northern part of the Republic of Tatarstan. It specializes in dairy and beef cattle breeding, production of grain and fodder crops, potatoes [5-7].
Next, we consider the main indicators of the state and development of agricultural sectors in the areas of PreKama zone of the Republic of Tatarstan.

As can be seen from table 1, the area of farmland and arable land in the areas of Pre-Kama economic zone has not changed much. Only in Baltasinsky, Mamadyshsky and Sabinsky districts there was an insignificant reduction in the area of farmland and arable land.

Table 1. Presence of farmland and arable land at the beginning of the year for agricultural enterprises, including peasant farms at the beginning of the year in the areas of Pre-Kama zone of the Republic of Tatarstan in 2015-2018, (thousand hectares)

\begin{tabular}{|c|c|c|c|c|c|c|c|c|}
\hline \multirow[b]{2}{*}{ Name of a district } & \multicolumn{2}{|c|}{2015} & \multicolumn{2}{|c|}{2016} & \multicolumn{2}{|c|}{2017} & \multicolumn{2}{|c|}{2018} \\
\hline & $\begin{array}{c}\text { Area of } \\
\text { agricultural } \\
\text { land } \\
\end{array}$ & $\begin{array}{c}\text { Including } \\
\text { arable } \\
\text { land } \\
\end{array}$ & $\begin{array}{c}\text { Area of } \\
\text { agricultural } \\
\text { land } \\
\end{array}$ & $\begin{array}{c}\text { Including } \\
\text { arable } \\
\text { land }\end{array}$ & $\begin{array}{c}\text { Area of } \\
\text { agricultural } \\
\text { land } \\
\end{array}$ & $\begin{array}{c}\text { Including } \\
\text { arable } \\
\text { land } \\
\end{array}$ & $\begin{array}{c}\text { Area of } \\
\text { agricultural } \\
\text { land } \\
\end{array}$ & $\begin{array}{c}\text { Including } \\
\text { arable } \\
\text { land } \\
\end{array}$ \\
\hline Baltasinsky & 77.1 & 69.9 & 77.7 & 70.6 & 77.8 & 70.7 & 76.9 & 69.9 \\
\hline Kukmorsky & 90.6 & 76.2 & 90.6 & 76.2 & 90.6 & 76.2 & 90.6 & 76.2 \\
\hline Mamadyshsky & 130.5 & 88.4 & 130.5 & 88.4 & 130.5 & 89.7 & 130.5 & 89.7 \\
\hline Rybno-Slobodsky & 104.8 & 84.6 & 104.8 & 84.6 & 104.8 & 84.6 & 104.8 & 84.6 \\
\hline Sabinsky & 63.5 & 58.3 & 63.5 & 58.3 & 63.5 & 58.3 & 63.2 & 58.0 \\
\hline Tyulyachinsky & 58.1 & 48.7 & 58.1 & 48.7 & 58.1 & 48.7 & 58.1 & 48.7 \\
\hline Total for the RT & 3973 & 3246 & 3941 & 3227 & 3939 & 3231 & 3943 & 3232 \\
\hline
\end{tabular}

In order to assess efficiency of land resources in the regions of the Republic of Tatarstan, we start with the production output of main types of agricultural products per 100 hectares of land (tables 2, 3).

Table 2. Milk production per 100 ha of farmland c

\begin{tabular}{|l|c|c|c|c|c|c|c|}
\hline \multirow{2}{*}{ Name of a district } & 2013 & 2014 & 2015 & 2016 & 2017 & \multicolumn{2}{|c|}{$2017 \%$} \\
\cline { 5 - 9 } & & & & & & 2016 & 2013 \\
\hline Baltasinsky & 784 & 811 & 869 & 922 & 992 & 108 & 134 \\
\hline Kukmorsky & 577 & 640 & 751 & 858 & 973 & 113 & 192 \\
\hline Mamadyshsky & 339 & 403 & 383 & 409 & 444 & 109 & 169 \\
\hline Rybno-Slobodsky & 132 & 137 & 145 & 159 & 160 & 101 & 121 \\
\hline Sabinsky & 693 & 724 & 805 & 842 & 914 & 108 & 139 \\
\hline Tyulyachinsky & 358 & 368 & 346 & 375 & 393 & 105 & 127 \\
\hline Total for the RT & 283 & 295 & 305 & 322 & 328 & 102 & 122 \\
\hline
\end{tabular}

As can be seen from table 2, in all areas of Pre-Kama economic zone, there is an increase in milk production per 100 hectares of farmland. The greatest growth is observed in Kukmorsky area. In 2017, compared with 2013 , the growth was $92 \%$, and compared to 2016 $13 \%$. There is also a high increase in milk production in Mamadyshsky district - $69 \%$. The smallest growth among the regions of Pre-Kama zone of the Republic of Tatarstan occurred in Rybno-Slobodsky district. The highest milk production per 100 hectares of farmland in Baltasinsky district of the Republic of Tatarstan is 992 $\mathrm{lb}$. The smallest milk production is observed in Rybno Sloboda district - 160 centners per 100 hectares of farmland, which is 6.2 times less than in Baltasinsky and
2 times compared with the average for the Republic of Tatarstan.

As can be seen from table 3, there is an increase in grain production per 100 hectares of arable land in Mamadysh and Rybno-Slobodsky dictricts of the Republic of Tatarstan. It is especially pronounced in Mamadysh district. Compared to 2013, the increase was $118 \%$. In other areas, there is a decrease in production. And the highest grain production per 100 hectares of arable land in 2017 in Rybno-Slobodsky district, which is $1284 \mathrm{lb}$. The smallest grain production per 100 hectares of arable land is observed in Tyulyachinsky district - 1009 lb. [5]

As can be seen from table 4, grain production in the areas of Pre-Kama zone is efficient. It is profitable in all areas of Pre-Kama zone in 2017-2018. The largest profitability of grain production is observed in Mamadyshsky district, in 2018 it is higher than the national average by 35 percentage points. The smallest profitability of grain production in 2018 in Tyulyachinsky district was $8.3 \%$. [5]

Table 3. Grain production per 100 ha of arable land, lb

\begin{tabular}{|l|c|c|c|c|c|c|c|}
\hline \multirow{2}{*}{ Name of a district } & 2013 & 2014 & 2015 & 2016 & 2017 & $2017 \%$ \\
\cline { 7 - 9 } & & & & & 2016 & 2013 \\
\hline Baltasinsky & 1606 & 1478 & 1455 & 1504 & 1259 & 84 & 78 \\
\hline Kukmorsky & 1175 & 1142 & 1253 & 1398 & 1127 & 81 & 96 \\
\hline Mamadyshsky & 996 & 830 & 1174 & 1347 & 1173 & 87 & 118 \\
\hline Rybno-Slobodsky & 1230 & 1275 & 1412 & 1674 & 1284 & 77 & 104 \\
\hline Sabinsky & 1167 & 1060 & 1207 & 1495 & 1149 & 77 & 99 \\
\hline Tyulyachinsky & 1065 & 898 & 1128 & 1242 & 1009 & 81 & 95 \\
\hline Total for theRT & 1035 & 1037 & 1265 & 1506 & 1132 & 75 & 109 \\
\hline
\end{tabular}


Table 4. Efficiency of grain production in the areas of Pre-Kama zone of the Republic of Tatarstan in 2017-2018

\begin{tabular}{|c|c|c|c|c|c|c|c|c|}
\hline \multirow{2}{*}{$\begin{array}{c}\text { Name of } \\
\text { adistrict }\end{array}$} & \multicolumn{2}{|c|}{ cost of 1 c. real. prod., rubles } & \multicolumn{2}{l|}{ Real price for1 lb., rubles } & \multicolumn{2}{c|}{ Profit (+), loss (-), thousand rubles } & \multicolumn{2}{c|}{ Profitability, \% } \\
\cline { 2 - 10 } & 2017 & 2018 & 2017 & 2018 & 2017 & 2018 & 2017 & 2018 \\
\hline Baltasinsky & 592 & 640 & 687 & 695 & 29472 & 17568 & 16.0 & 8.6 \\
\hline Kukmorsky & 550 & 573 & 630 & 698 & 29460 & 38370 & 14.6 & 22.0 \\
\hline Mamadyshsky & 352 & 426 & 587 & 626 & 97177 & 93663 & 66.9 & 46.9 \\
\hline $\begin{array}{c}\text { Rybno- } \\
\text { Slobodsky }\end{array}$ & 552 & 718 & 672 & 818 & 50588 & 77936 & 21.6 & 13.9 \\
\hline Sabinsky & 545 & 540 & 639 & 721 & 36187 & 59674 & 17.3 & 33.4 \\
\hline Tyulyachinsky & 561 & 677 & 613 & 734 & 13669 & 13743 & 9.3 & 8.3 \\
\hline Total for the RT & 577 & 715 & 627 & 800 & 1019022 & 1881168 & 8.7 & 11.9 \\
\hline
\end{tabular}

Table 5. Potato production efficiency in the areas of Pre-Kama zone of the Republic of Tatarstan in 2017-2018

\begin{tabular}{|l|c|c|c|c|c|c|c|c|}
\hline \multirow{2}{*}{ Name of a district } & \multicolumn{2}{|c|}{ cost of 1 c. real. prod., rubles } & \multicolumn{2}{c|}{ Real price 1 lb., rubles } & \multicolumn{2}{l|}{ Profit (+), loss (-), thousand rubles } & \multicolumn{2}{c|}{ Profitability, \% } \\
\cline { 2 - 9 } & 2017 & 2018 & 2017 & 2018 & 2017 & 2018 & 2017 & 2018 \\
\hline Baltasinsky & 732 & 625 & 1260 & 1045 & 6905 & 6776 & 72.1 & 67.1 \\
\hline Kukmorsky & 727 & 513 & 1203 & 799 & 11096 & 8033 & 65.4 & 55.7 \\
\hline Mamadyshsky & 347 & 615 & 307 & 667 & -739 & 251 & -11.6 & 8.3 \\
\hline Rybno-Slobodsky & - & - & - & - & - & - & - & - \\
\hline Sabinsky & 878 & 658 & 1022 & 697 & 4191 & 525 & 16.3 & 5.9 \\
\hline Tyulyachinsky & 705 & - & 717 & - & 44 & - & 1.8 & - \\
\hline Total for the RT & 786 & 797 & 949 & 927 & 68102 & 51801 & 20.8 & 16.3 \\
\hline
\end{tabular}

As can be seen from table 5, potato production is not effective in all areas of Pre-Kama zone. Mamadyshsky district in 2017 suffered losses in the production of potatoes. In Rybno-Slobodsky district, potatoes are not cultivated on farms. The highest profitability of potato production in 2018 is observed in Baltasinsky district of
$67.1 \%$ and Kukmorsky district of $55.7 \%$, which is 50.8 and 39.4 percentage points higher than the national average, respectively. The lowest profitability of potato production in 2018 in Sabinsky district was $5.9 \%$. In Tyulyachinsky district potatoes were not cultivated in 2018.

Table 6. Efficiency of milk production in the areas of Pre-Kama zone of the Republic of Tatarstan in 2017-2018

\begin{tabular}{|c|c|c|c|c|c|c|c|c|}
\hline \multirow{2}{*}{$\begin{array}{c}\text { Name of a } \\
\text { district }\end{array}$} & \multicolumn{2}{|c|}{ cost of 1 c. real. prod., rubles } & \multicolumn{2}{|c|}{ Real price $1 \mathrm{lb}$. , rubles } & \multicolumn{2}{|c|}{ Profit $(+)$, loss $(-)$, thousand rubles } & \multicolumn{2}{|c|}{ Profitability, $\%$} \\
\hline & 2017 & 2018 & 2017 & 2018 & 2017 & 2018 & 2017 & 2018 \\
\hline Baltasinsky & 1604 & 1622 & 2296 & 1966 & 457700 & 243140 & 43.1 & 21.2 \\
\hline Kukmorsky & 1547 & 1531 & 2207 & 1922 & 447700 & 296683 & 42.7 & 25.5 \\
\hline Mamadyshsky & 1677 & 1856 & 2344 & 1947 & 309777 & 44115 & 39.8 & 4.9 \\
\hline \begin{tabular}{|l|} 
Rybno- \\
Slobodsky \\
\end{tabular} & 2093 & 1807 & 2340 & 1989 & 20021 & 13646 & 11.8 & 10.1 \\
\hline Sabinsky & 1827 & 1794 & 2369 & 2003 & 264449 & 109815 & 29.7 & 11.6 \\
\hline Tyulyachinsky & 1926 & 1715 & 2269 & 1873 & 59017 & 27340 & 17.8 & 9.2 \\
\hline Total for the RT & 1776 & 1770 & 2228 & 1943 & 4499580.7 & 1812258 & 25.4 & 9.8 \\
\hline
\end{tabular}

As can be seen from table 6 , milk production in the areas of Pre-Kama zone is effective. It is profitable in all areas of Pre-Kama zone in 2017-2018. The highest profitability of milk production in 2018 is observed in Kukmorsky District, $25.5 \%$, and Baltasinsky District, $21.2 \%$, which is 15.7 and 11.4 percentage points higher than the national average, respectively. At the same time, the profitability of milk production is reduced in all areas in 2018, compared with 2017. The lowest profitability of milk production in 2018 is observed in Mamadysh district of $4.9 \%$.

Table 7. Efficiency of cattle meat production in the areas of the Pre-Kama zone of the Republic of Tatarstan in 2017-2018

\begin{tabular}{|l|c|c|c|c|c|c|c|c|}
\hline \multirow{2}{*}{ Name of a district } & \multicolumn{2}{|c|}{$\begin{array}{c}\text { cost of 1 c. real. prod., } \\
\text { rubles }\end{array}$} & \multicolumn{2}{c|}{ Real price 1 c., rubles } & \multicolumn{2}{c|}{$\begin{array}{c}\text { Profit (+), loss (-), thousand } \\
\text { rubles }\end{array}$} & \multicolumn{2}{c|}{ Profitability, \% } \\
\cline { 2 - 9 } & 2017 & 2018 & 2017 & 2018 & 2017 & 2018 & 2017 & 2018 \\
\hline Baltasinsky & 11782 & 12081 & 10678 & 10678 & -52632 & -73791 & -9.4 & -11.6 \\
\hline Kukmorsky & 10494 & 11547 & 9340 & 10168 & -55441 & -67446 & -11.0 & -11.9 \\
\hline Mamadyshsky & 10882 & 13351 & 8368 & 11344 & -138620 & -98652 & -23.1 & -15.0 \\
\hline Rybno-Slobodsky & 13191 & 14399 & 12014 & 12291 & -11698 & -15798 & -8.9 & -14.6 \\
\hline Sabinsky & 14156 & 13990 & 10556 & 10702 & -132649 & -139747 & -25.4 & -23.5 \\
\hline Tyulyachinsky & 11057 & 11382 & 10161 & 10632 & -13871.3 & -12857.5 & -8.1 & -6.6 \\
\hline Total for the RT & 13611 & 13919 & 10441 & 10813 & -2990050 & -2878247 & -23.3 & -22.3 \\
\hline
\end{tabular}


As can be seen from table 7, cattle meat production is unprofitable in all areas of Pre-Kama zone. All areas suffered losses in cattle meat production in 2017-2018. The largest loss-making cattle meat production in 2018 is observed in Sabinsky and Mamadyshsky districts. The smallest loss ratio in 2018 in Tyulyachinsky district accounts for $6.6 \%$.

As can be seen from tables 8 and 9, crop and livestock production in areas of Pre-Kama zone of the Republic of
Tatarstan in 2017-2018 is efficient, except for livestock production in Mamadysh and Rybno-Slobodsky districts in 2018. The highest profitability of crop production in 2018 was observed in Mamadyshsky district - 34.9\%, livestock breeding in Baltasinsky and Kukmorsky districts. The least profitability of crop production in 2017 was observed in the Tyulyachinsky district, and RybnoSlobodsky and Mamadyshsky districts of the Republic of Tatarstan have suffered losses.

Table 8. Efficiency of crop production in the areas of Pre-Kama zone of the Republic of Tatarstan in 2017-2018

\begin{tabular}{|l|c|c|c|c|c|c|c|c|}
\hline \multirow{2}{*}{ Name of a district } & \multicolumn{2}{|c|}{$\begin{array}{c}\text { Realized product cost, } \\
\text { million rubles }\end{array}$} & \multicolumn{2}{c|}{$\begin{array}{c}\text { Revenues from sales, } \\
\text { thousand rubles }\end{array}$} & \multicolumn{2}{c|}{$\begin{array}{c}\text { Profit (+), loss (-), } \\
\text { thousand rubles }\end{array}$} & \multicolumn{3}{c|}{ Profitability, \% } \\
\cline { 2 - 10 } & 2017 & 2018 & 2017 & 2018 & 2017 & 2018 & 2017 & 2018 \\
\hline Baltasinsky & 1736.8 & 1858.3 & 2136.4 & 2026.0 & 399.6 & 167.8 & 23.0 & 9.0 \\
\hline Kukmorsky & 1666.7 & 1771.0 & 2052.7 & 2002.1 & 386.0 & 231.0 & 23.2 & 13.0 \\
\hline Mamadyshsky & 1452.5 & 1644.0 & 1617.9 & 1572.2 & 165.4 & -71.8 & 11.4 & -4.4 \\
\hline Rybno-Slobodsky & 423.9 & 354.1 & 432.0 & 353.2 & 8.0 & -1.0 & 1.9 & -0.3 \\
\hline Sabinsky & 2202.1 & 2287.6 & 2441.7 & 2429.6 & 239.5 & 141.9 & 10.9 & 6.2 \\
\hline Tyulyachinsky & 559.0 & 552.0 & 605.6 & 567.9 & 46.6 & 15.9 & 8.3 & 2.9 \\
\hline Total for the RT & 53719.7 & 55920.4 & 59102.3 & 59476.1 & 5382.6 & 3555.7 & 10.0 & 6.3 \\
\hline
\end{tabular}

Table 9. Profit (loss) and profitability in agriculture in the areas of Pre-Kama zone of the Republic of Tatarstan for 2017-2018

\begin{tabular}{|c|c|c|c|c|c|c|c|c|}
\hline \multirow{3}{*}{ Name of a district } & \multicolumn{4}{|c|}{ Number of households } & \multirow{2}{*}{\multicolumn{2}{|c|}{$\begin{array}{l}\text { Profit }+, \text { loss }-(\text { before tax }), \\
\text { thousand rubles }\end{array}$}} & \multirow{2}{*}{\multicolumn{2}{|c|}{ Profitability, $\%$}} \\
\hline & \multicolumn{2}{|c|}{ Total } & \multicolumn{2}{|c|}{ Including profitable ones } & & & & \\
\hline & 2017 & 2018 & 2017 & 2018 & 2017 & 2018 & 2017 & 2018 \\
\hline Baltasinsky & 22 & 22 & 22 & 22 & 522746 & 373197 & 25.6 & 17.0 \\
\hline Kukmorsky & 15 & 15 & 15 & 14 & 277274 & 533130 & 12.9 & 24.7 \\
\hline Mamadyshsky & 14 & 11 & 11 & 10 & 592467 & 241577 & 32.9 & 11.4 \\
\hline Rybno-Slobodsky & 14 & 13 & 12 & 11 & 143932 & 203593 & 16.3 & 17.3 \\
\hline Sabinsky & 19 & 19 & 19 & 18 & 481033 & 586072 & 17.9 & 22.0 \\
\hline Tyulyachinsky & 14 & 12 & 13 & 10 & 118316 & 77104 & 15.2 & 10.1 \\
\hline Total for the RT & 486 & 463 & 443 & 425 & 7933933 & 8826528 & 9.6 & 10.1 \\
\hline
\end{tabular}

As can be seen from table 10, there were 4 unprofitable farms in Mamadyshsky district, 3 of them in Rybno-Slobodsky district, 4 in Tyulyachinsky district, 1 in Kukmorsky district, and 1 in Sabinsky district.

In general, agricultural production in the areas of PreKama zone in 2017-2018 was efficient.

The highest profitability of agricultural production in 2018 is observed in Kukmorsky district $-24.7 \%$ and in Sabinsky district $-22.0 \%$. The lowest profitability of production in 2018 is observed in Tyulyachinsky district $-10.1 \%$.

Based on the analysis of the effectiveness of the functioning of agricultural enterprises in the areas of PreKama zone of the Republic of Tatarstan, it can be concluded that the state and effectiveness of agricultural sectors are very high.

Analysis of the results of the branches' state and the efficiency of agricultural enterprises' functioning allows us to determine the limiting factors and reserves for its increase. For the full use of existing reserves, it is necessary to develop a set of organizational and economic measures aimed at improving the functioning of agricultural organizations.

\section{Conclusion}

Improving the economic efficiency of agricultural production is associated with solving a whole range of problems. The solution to these problems is determined by both subjective and objective factors. First of all, improving the efficiency of the crop and livestock industry [7-10].

The main ways to increase economic efficiency are:

- development of additional types of entrepreneurship;

- maximum participation in state support programs for agriculture;

- conducting market research to develop new segments and channels of the market;

- use of own resources and reducing the share of borrowed funds in the implementation of investment activities;

- development of measures to reduce the cost of production;

- creation of a reserve fund to ensure unforeseen expenses;

- transition to high-tech equipment and introduction of low-cost energy-saving technologies in crop and livestock production;

- modernization of existing equipment, the exchange of old equipment for new;

- uniform income generation due to an increase in the share of livestock production;

- the use of new high-yielding plant varieties and early productive animal breeds; 
- development of organic agriculture;

- development of the feed base, providing livestock mainly with their own feed;

- use of advanced technologies in animal husbandry;

- disease prevention and proper treatment of animals;

- further reclamation and chemicalization of agricultural land;

- improving the structure of sown areas and crop rotation systems;

- reduction of product losses during their storage, transportation, processing;

- selection of effective ways and channels of product sales;

- advanced training and currentity of personnel in agriculture;

- improving planning and forecasting;

- increasing the motivation of workers to highly productive labor;

- improvement of the economic mechanism of managing.

\section{References}

1. A.K. Subaeva, M.M. Nizamutdinov, L.M. Mavlieva, M.N. Kalimullin, Labor productivity in digital agriculture, BIO Web of Conf., 00226 (2020)

2. A.R. Battalova, O.A. Ignatjeva, F.N. Mukhametgaliev, L.F. Sitdikova, Organizational and economic mechanism of improving the efficiency of grain production at the regional level, Int. J. on Emerg. Technol., 10(2), 112-116 (2019)

3. A.R. Battalova, R.S. Tukhvatullin, F.N. Mukhametgaliev, F.F. Mukhametgalieva, Priority areas of development of agricultural entrepreneurship in the regions of the Russian
Federation, Int. J. on Emerg. Technol., 10(2), 133136 (2019)

4. F.N. Mukhametgaliev, L.F. Sitdikova, M.M. Khismatullin, N.M. Asadullin L.V. Mikhailova, Prospects of agricultural business in the republic of Tatarstan, BIO Web of Conf., 00083 (2020)

5. F.N. Mukhametgaliev, L.F. Sitdikova, F.N. Avkhadiev, I.G. Gainutdinov, V.Ya. Petrova, Problems of regional grain market development, BIO Web of Conf., 00082 (2020)

6. E.F. Amirova, I.N. Safiullin, L.G. Ibragimov, N.V. Karpova, State regulation of the agricultural sector in the context of sanctions and the development of digital economy, Bull. of Kazan State Agrar. Univer., 14(3(54)), 133-137 (2019)

7. F.N. Mukhametgaliev, L.F. Sitdikova, F.F. Mukhametgalieva, F.N. Avkhadiev et al., Trends in the formation of the current agrifood policy of Russia, Stud. on Russ. Econ. Developm., 30(2), 162-165 (2019)

8. D.F. Khafizov, M.M. Khismatullin, E.S. Isaicheva, Improving the forms of ownership and management on the basis of attracting investments, development of cooperation and agro-industrial integration, Econ. of agricult. and proc. enterpr., 3, 25-26 (2006)

9. N.M. Asadullin, M.M. Khismatullin, L.N. Asadullin, The concept of efficient use of resources during the technical operation of agricultural machinery, Bull. of Kazan State Agrar. Univer., 6(3(21)), 17-19 (2011)

10. F.N. Mukhametgaliev, L.V. Mikhailova, Methodological features of development planning of enterprises of small business forms in agriculture, Competitiveness in the global world: econ., sci., technol., 7-4(54), 100-103 (2017) 